\title{
A SOUTH-SOUTH SURVIVAL STRATEGY: THE POTENTIAL FOR TRADE AMONG DEVELOPING COUNTRIES
}

\author{
by \\ Marco Fugazza \\ Trade Analysis Branch \\ Division on International Trade in Goods and Services, and Commodities \\ UNCTAD \\ and

\section{David Vanzetti} \\ Asia Pacific School of Economics and Government \\ The Australian National University, Canberra

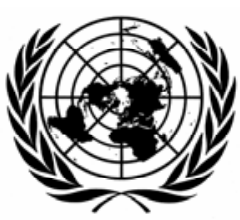 \\ UNITED NATIONS \\ New York and Geneva, 2006
}




\section{NOTE}

The purpose of this series of studies is to analyse policy issues and to stimulate discussions in the area of international trade and development. This series includes studies by UNCTAD staff, as well as by distinguished researchers from academia. In keeping with the objective of the series, authors are encouraged to express their own views, which do not necessarily reflect the views of the United Nations.

The designations employed and the presentation of the material do not imply the expression of any opinion whatsoever on the part of the United Nations Secretariat concerning the legal status of any country, territory, city or area, or of its authorities, or concerning the delimitation of its frontiers or boundaries.

Material in this publication may be freely quoted or reprinted, but acknowledgement is requested, together with a reference to the document number. It would be appreciated if a copy of the publication containing the quotation or reprint were sent to the UNCTAD secretariat:

\section{Chief}

Trade Analysis Branch

Division on International Trade in Goods and Services, and Commodities United Nations Conference on Trade and Development

Palais des Nations

CH-1211 Geneva

Series Editor:

Khalilur Rahman

Chief, Trade Analysis Branch

DITC/UNCTAD

UNCTAD/ITCD/TAB/34

\section{UNITED NATIONS PUBLICATION}

ISSN 1607-8291

(C) Copyright United Nations 2006

All rights reserved 


\begin{abstract}
Trade between developing countries, or South-South trade, has been growing rapidly in recent years following significant reductions in tariff barriers. However, significant barriers remain, and there is currently reluctance in many developing countries to undertake further reductions, with a preference instead for focusing on opening up access to developed country markets, or maintaining the status quo given that multilateral liberalization may result in the erosion of preferential access enjoyed by some developing countries.

This emphasis on Northern markets represents a missed opportunity for developing countries. To assess this we compare the potential effects of the removal of barriers on SouthSouth trade with the gains from developed country liberalization and from regional free trade areas within Africa, Asia and Latin America. A general equilibrium model, GTAP, containing information on preferential bilateral tariffs, is used to estimate the impacts. The results indicate that the opening up of Northern markets would provide annual welfare gains to developing countries of $\$ 22$ billion. However, the removal of South-South barriers has the potential to generate gains 60 per cent larger. By contrast, the potential gains from further regional agreements on a continental basis are limited in Africa and Asia, although scope remains in Latin America. The results imply that giving greater emphasis to removing barriers between as well as within continents could prove a successful Southern survival strategy.
\end{abstract}




\section{ACKNOWLEDGEMENTS}

We are grateful to Jörg Mayer, seminar participants at UNCTAD and participants at the 8th Annual Conference on Global Economic Analysis for helpful comments and discussions. All conclusions and remaining errors are of course ours. 


\section{CONTENTS}

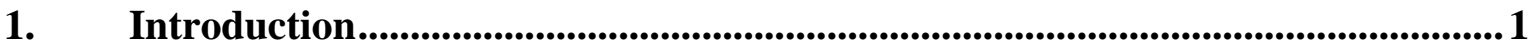

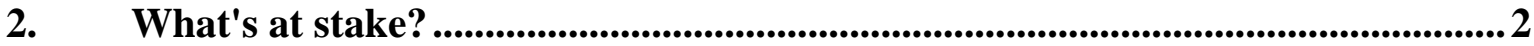

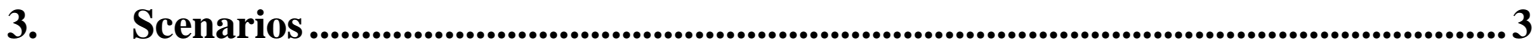

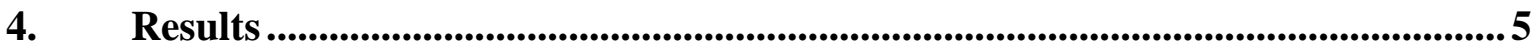

Welfare .............................................................................................................................5 5

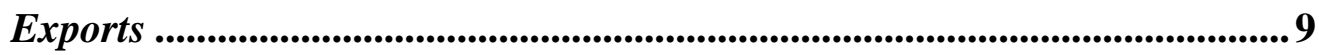

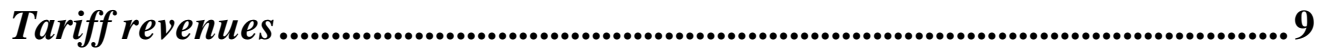

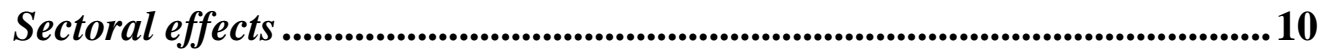

5. Concluding remarks and implications .........................................................

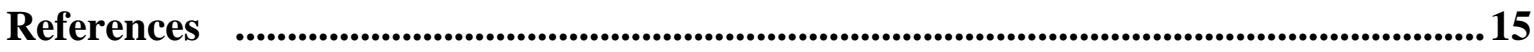




\section{Tables}

1. Trade-weighted average applied tariffs (including preferences)

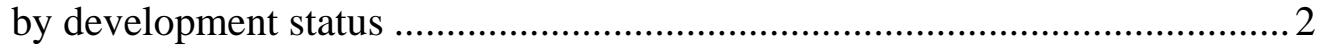

2. Trade-weighted average agricultural applied tariffs (including preferences) by development status and degree of processing........................................... 3

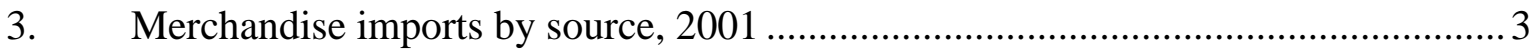

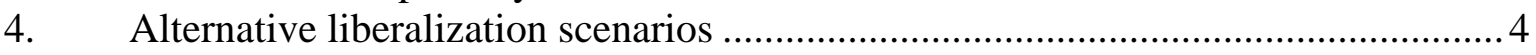

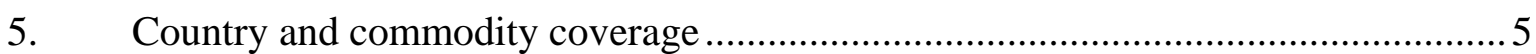

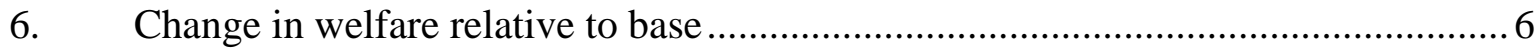

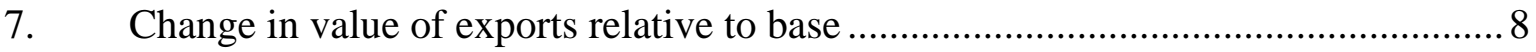

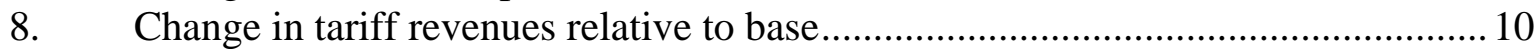

9. Changes in output values by economic sector ........................................................ 12

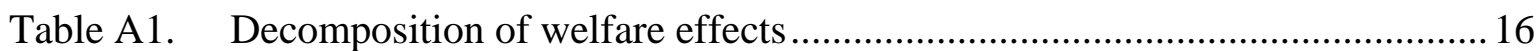

Table A2. Change in sectoral exports relative to base

from South-South liberalization .................................................................. 18

Table A3. Change in output relative to base from South-South liberalization ............... 19

Table A4. Initial share in total world sectoral output .................................................. 20 


\section{INTRODUCTION}

Most trade negotiators appear to take a mercantilist view of regional and multilateral trade negotiations, aiming to obtain improved access for their exports while limiting the access other countries have to their domestic markets. In particular, developing countries are keen to access the major developed countries, namely the United States, the European Union and Japan. However, this emphasis may be misplaced. There is significant scope for improving trade among developing countries themselves. By seeking exemptions for sensitive products in their markets, developing countries are inadvertently limiting the trade opportunities of other developing countries.

Various studies look at the effects of the establishment of regional trade agreements (RTAs). For instance, Venables (2003) reaches the conclusion that benefits from South-South trade agreements are likely to be small and generate trade diversion. In other words, production patterns in Southern countries induced by the trade agreement are unlikely to correspond to their true underlying comparative advantage. The logic of the argument is rooted in neoclassical trade theory, with patterns of comparative advantage being exogenous and immutable. In other approaches, such as the so-called 'new economic geography' (Fujita, Krugman and Venables, 1999), cumulative causation mechanisms at the core of the formation of industrial clusters 'endogenise' the comparative advantage variable. In such a setting, the qualification of the impact of RTAs goes beyond the trade creation versus trade diversion dimension. For instance, by combining the standard features of the new trade theory and forward and backward linkages among firms, Puga and Venables (1998 and 1999) find more qualified results, although they also argue that North-South preferential trade agreements are likely to offer better prospects for Southern countries, including for non-participating ones. Fugazza and Robert-Nicoud (2006) show that SouthSouth trade can have the effect of lowering the price of intermediate inputs and eventually allows exporters in those countries to serve international markets.

In this paper we examine the potential for gains from liberalization of South-South trade and compare this with the impacts of developed countries opening up their markets. We use the recently released version 6 GTAP database, which includes preferential tariffs. This differs from previous versions that did not include preferential data. GTAP, a deterministic, comparative static, general equilibrium trade model, is used to assess the potential impacts. We start by examining recent trade flows, identify the existing barriers, and quantify the impacts on developed countries of eight alternative scenarios: developed country liberalization; liberalization between developing countries only; and regional trade agreements within sub-Saharan Africa; the Middle East and North Africa; Africa and the Middle East; Latin America and the Caribbean; and Asia respectively. We also simulate the three regional agreements simultaneously to illustrate the importance of links between as well as within regions. Regional agreements have appeared to be politically much more feasible on a continental basis than between all developing countries. However, the launch of the third round of GSTP negotiations in June 2004 may change this perception. The Global System of Trade Preferences among Developing Countries envisages preferential trade arrangements among 43 developing countries from all regions, and accession will be opened to China and the Group of 77 . 
The results indicate that there are significant potential gains from South-South trade liberalization, although part of these gains can be harvested from regional agreements. Policy implications, limitations and conclusions bring the paper to a close.

\section{WHAT'S AT STAKE?}

Many developing and least developed countries enjoy tariff preferences under the generalized system of preferences and more selective schemes, such as the Cotonou Agreement, the Caribbean Basin Initiative, the EU's Everything But Arms initiative and the United States' African Growth and Opportunities Act (AGOA) (UNCTAD 2003). Even taking account of these preferences, average import-weighted applied tariffs on exports from these regions to developed countries are higher than those facing developed countries themselves. This reflects the composition of imports with different tariffs rather than higher tariffs on the same item. It also reflects the relatively weak bargaining power of the developing countries in past rounds of negotiations in that they were unable to secure tariff cuts on the kind of goods that they export.

Table 1 shows trade-weighted applied tariffs levied by developed and developing countries on merchandise exports from each other. These data include preferential rates. On average, developed countries impose tariffs of 2.1 per cent on imports from other developed countries, 3.9 per cent on imports from developing countries and 3.1 per cent on imports from LDCs. The most significant sectors contributing to the higher tariffs on developing country exports are textiles, apparel and leather. On the other hand, developed countries also face higher tariffs when exporting to developing countries (9.2 per cent) than do other developing countries (7.2 per cent), partly reflecting the composition of trade and partly reflecting preferential arrangements among groups of developing countries.

Agriculture alone tells a slightly different story (table 2), with high protection applied in both developed and developing countries against products from both groups. Developed countries, however, give greater access to least developed country products (2 per cent) than do developing countries (12 per cent). This reflects the various preferential schemes previously mentioned. However, protection is applied predominantly against temperate products grown in other developed countries with similar agronomic and climatic conditions. Typical developing country products such as coffee and tropical fruits are not particularly substitutable with temperate products. Notable exceptions are sugar (cane and beet sugar are substitutes), vegetable oils, tobacco and cotton. Many tropical products, such as coffee, attract little protection in developed countries. However, many developing countries have substantial tariffs on tropical commodities.

Table 1. Trade-weighted average applied tariffs (including preferences) by development status (Percentages)

\begin{tabular}{lccc}
\hline Source & Developed & Developing & Least developed \\
\hline Developed & 2.1 & 9.2 & 11.1 \\
Developing & 3.9 & 7.2 & 14.4 \\
Least developed & 3.1 & 7.2 & 8.3 \\
Total & 2.9 & 8.1 & 13.6 \\
\hline
\end{tabular}

Source: Computed from WITS/TRAINS (2004) database. 
Table 2. Trade-weighted average agricultural applied tariffs (including preferences) by development status and degree of processing

(Percentages)

\begin{tabular}{|c|c|c|c|c|c|c|}
\hline \multirow[t]{2}{*}{ Source } & \multicolumn{2}{|c|}{ Developed } & \multicolumn{2}{|c|}{ Developing } & \multicolumn{2}{|c|}{ Least developed } \\
\hline & Un-processed & Processed & Un-processed & Processed & Un-processed & Processed \\
\hline Developed & 9.0 & 17.3 & 15.5 & 17.3 & 5.3 & 16.2 \\
\hline Developing & 7.8 & 13.5 & 17.3 & 17.2 & 10.7 & 14.5 \\
\hline Least developed & 2.3 & 7.6 & 11.8 & 18.5 & 4.8 & 12.1 \\
\hline
\end{tabular}

Source: Computed from WITS/TRAINS (2004) database, latest available.

Trade-weighted tariffs are averaged by imports, but it is instructive to look at the trade flows themselves to gauge the likely impacts. These are shown in table 3. Total trade in merchandise at world prices amounts to $\$ 5.5$ billion (2001) (excluding intra-EU trade). Developed countries import $\$ 1.8$ billion from other developed countries and slightly more than $\$ 1.2$ billion from developing (including least developed) countries. Developing countries themselves import a greater proportion of their imports from developed countries ( $\$ 1.19$ billion versus $\$ 0.9$ billion) but South-South trade is a substantial proportion nonetheless. Taking into account trade flows, the imputed tariff revenues collected by developed countries amounts to $\$ 76$ billion. By contrast, developing countries are collecting an estimated $\$ 152$ billion. Of this, $\$ 83$ billion is on imports from developed countries and $\$ 69$ billion on imports from other developing countries.

Table 3. Merchandise imports by source, 2001

(Thousands of US dollars)

\begin{tabular}{llr}
\hline Source & Developed & Developing \\
\hline Developed & 1768340 & 1188810 \\
Developing & 1225821 & 903627 \\
Total & 2957150 & 2129448 \\
\hline
\end{tabular}

Source: Computed from GTAP 6 database.
The high tariff burden on South-South trade poses the question as to whether developing countries could assist their development by trading more with each other. One advantage is their proximity, which may imply lower transport costs. In addition, other developing countries, by definition at a similar stage of development, may not have the competitive advantage of developed countries. Thus, developing countries opening their markets are less likely to be swamped with imports. On the other hand, the benefits of trade come from divergences in relative factor endowments and costs, and there are fewer potential gains available from trading with countries that have endowments and cost structures similar to one's own.

\section{SCENARIOS}

To assess the potential gains from liberalization with different groups, we postulate eight scenarios that are presented in table 4 . In each case there are no reductions in the services sectors.

Simulations are undertaken using the GTAP version 6 database (GTAP 2005). The database has 87 countries and regions and 57 sectors that are aggregated as shown in table 5. The group 'Other Asia' includes the Republic of Korea and Taiwan Province of China. ${ }^{1}$ The remaining groups are self-

\footnotetext{
1 This group is treated here as a developing country region.
} 
North

South-South

Southern RTAs

Asia

Latin America and the Caribbean

Sub-Saharan

Africa (SSA)

Middle East and North Africa

(MENA)

MENA and SSA
Elimination of all import and export taxes and subsidies in developed countries on trade with all countries.

Elimination of all import and export taxes and subsidies in developing countries on trade with other developing countries.

Elimination of all import and export taxes and subsidies in developing countries in Asia, Latin America and Africa on trade with other developing countries in their region. This is a combination of the scenarios below. Two versions are considered: one that looks at SSA and MENA countries separately (RTAs(1)), one jointly (RTAs(2)).

Elimination of all import and export taxes and subsidies in developing Asian countries on trade with other developing countries in the region.

Elimination of all import and export taxes and subsidies in developing Latin American countries on trade with other developing countries in the region.

Elimination of all import and export taxes and subsidies in developing SubSaharan African countries on trade with other developing countries in the region.

Elimination of all import and export taxes and subsidies in Middle Eastern and North African developing countries on trade with other developing countries in the region.

Elimination of all import and export taxes and subsidies in Middle Eastern and African (northern and sub-Saharan) developing countries on trade with other developing countries in the region. explanatory. The sectoral aggregation attempts to split out sectors with significant protection, such as textiles, apparel, motor vehicles and electronics. The database includes tariffs, export subsidies and taxes, and subsidies on output and on inputs such as capital, labour and land. Border measures are specified bilaterally, so the impact of preference erosion can be ascertained. Preferential tariffs are included in the initial database. Quota rents in textiles and apparel are modelled as export taxes, implying that the rents accrue to exporting Governments. The data applies to 2001. However, following Anderson, Martin and Mensbrugghe (2005), we first conduct a pre-simulation that implements pre-existing WTO commitments not implemented as of 2001. These include the phase-out of export quotas on textiles and apparel directed to the United States and the European Union and the implementation of commitments made by newly acceding WTO members, notably China. We also implement the European Union enlargement. The data set obtained from that pre-simulation becomes the base for our analysis.

GTAP is a general equilibrium model that includes linkages between economies and between sectors within economies. Industries are assumed to be perfectly competitive and are characterized by constant returns to scale. Imports are distinct from domestically produced goods, as are imports from alternative sources. Primary factors are substitutable but as a composite are used in fixed proportions to intermediate inputs. We use the standard GTAP closure modified to 
Table 5. Country and commodity coverage

\begin{tabular}{l|l}
\hline Regions & Sectors \\
\hline European Union & Cereals \\
USA, rest of North America & Vegetables, fruits and nuts \\
Japan & Vegetable oils \\
Other developed & Sugar \\
China & Other crops \\
Other Asia & Livestock \\
India & Resources \\
Other South Asia & Dairy \\
ASEAN & Other foods \\
Mexico & Textiles \\
Andean & Apparel \\
Mercosur & Leather \\
Rest of Latin America & Non metallic manufactures \\
Central America & Petroleum and coal products \\
Caribbean & Motor vehicles \\
\hline South Africa & Electronics \\
Sub-Saharan Africa & Manufactures \\
South African Development Communitya & Services \\
Middle East and North Africa & Transport \\
South-East Europe (SEE) & Business services \\
Rest of World & \\
\hline
\end{tabular}

${ }^{a}$ Excludes South Africa.

maintain fixed trade balances for all regions but the United States. ${ }^{2}$ This alternative closure is chosen in order to prevent balance-of-trade surpluses from increasing dramatically. ${ }^{3}$

\section{RESULTS}

The GTAP software and its companions generate a large set of results. Here we focus on four dimensions that we believe are relevant to illustrate the argument of the paper, namely welfare, exports, tariff revenues and sectoral effects.

\section{Welfare}

The results presented in table 6 indicate that South-South trade liberalization is the most favourable scenario to developing countries as a group. The static annual welfare gains to developing countries are estimated at $\$ 22$ billion from liberalization in the North and $\$ 35$ billion from South-South liberalization. ${ }^{4}$ Most developing regions gain from the removal of barriers between developing countries alone. Moreover, when losses are observed, they remain relatively small. The major beneficiaries are Other Asia (Republic of Korea and Taiwan, Province of

\footnotetext{
2 The GTAP model requires that imports minus exports equals investment less savings in each region. The standard macroeconomic closure allows investment to adjust to satisfy this condition. A current account deficit is offset by a capital inflow. In the closure used in this paper, capital in other regions would be absorbed by the United States whenever it exceeds regional savings.

3 See Francois et al. (1996) and Hertel et al. (1997) for a detailed discussion on the relevance of alternative closures.

4 The welfare measure used here is equivalent variation, the maximum amount of income the consumer is willing to pay to avoid a price change.
} 
China), ASEAN, Middle East and North African (MENA) countries, China and MERCOSUR countries. However, Central America and the Caribbean, India, subSaharan Africa (excluding SADC countries), Central and Eastern Europe and Other South Asia are net losers. So too are the developed countries. Tables A1 and A2 show that net losses are driven by negative terms-of-trade welfare effects. A more detailed analysis reveals that this is essentially the case in the manufacturing sectors, although India faces a strong negative effect in livestock and resources sectors. Net gains are the result of both positive allocative and terms-of-trade welfare effects. Positive allocative effects are driven principally by reforms in manufacturing sectors. However, in the case of the Other Asia region, reform in agricultural sectors and in particular the cereals sector is generating

Table 6. Change in welfare relative to base

(Thousands of US dollars)

\begin{tabular}{|c|c|c|c|c|c|c|c|c|c|c|}
\hline & $\begin{array}{l}\text { Free } \\
\text { trade }\end{array}$ & $\begin{array}{l}\text { North- } \\
\text { South }\end{array}$ & $\begin{array}{l}\text { South- } \\
\text { South }\end{array}$ & $\begin{array}{l}\text { Southern } \\
\text { RTAs(1) }\end{array}$ & $\begin{array}{l}\text { Southern } \\
\text { RTAs(2) }\end{array}$ & SSA & MENA & $\begin{array}{l}\text { SSA+ } \\
\text { MENA }\end{array}$ & LAC & Asia \\
\hline European Union & 24245 & -171 & -7681 & -3271 & -3485 & -159 & -842 & -1214 & -831 & -1422 \\
\hline United States & 7346 & -1751 & -7060 & -2547 & -2580 & -29 & -247 & -310 & -1402 & -852 \\
\hline North America & 727 & 636 & 204 & -8 & -2 & 7 & 33 & 46 & 3 & -52 \\
\hline Japan & 25977 & 16740 & -2838 & -1298 & -1322 & -13 & -224 & -260 & -192 & -868 \\
\hline Other developed & 3371 & 2234 & -582 & -305 & -301 & 1 & 16 & 20 & 16 & -335 \\
\hline Subtotal & 61666 & 17688 & -17957 & -7429 & -7690 & -193 & -1264 & -1718 & -2406 & -3529 \\
\hline China & 6453 & 7850 & 3381 & 906 & 874 & -19 & -146 & -198 & -53 & 1125 \\
\hline India & 475 & 779 & -449 & -1437 & -1483 & -45 & -135 & -228 & -27 & -1241 \\
\hline Other Asia & 13153 & 2776 & 16208 & 12387 & 12360 & -25 & -167 & -219 & -174 & 12673 \\
\hline Other South Asia & -979 & 294 & -170 & -212 & -217 & -4 & -43 & -53 & -1 & -163 \\
\hline ASEAN & 7450 & 5529 & 7309 & 871 & 845 & -16 & -86 & -127 & 17 & 963 \\
\hline Asia Subtotal & 26552 & 17228 & 26279 & 12515 & 12379 & -109 & -577 & -825 & -238 & 13357 \\
\hline Mexico & -68 & -1133 & 1192 & 879 & 882 & 4 & 8 & 14 & 861 & 7 \\
\hline Andean & -541 & 379 & 580 & -450 & -449 & 4 & 30 & 36 & -278 & -206 \\
\hline Mercosur & 4084 & 4270 & 2176 & 1703 & 1697 & -7 & -12 & -26 & 2008 & -308 \\
\hline Rest of Latin America & 380 & 851 & 43 & 371 & 370 & -1 & 0 & -1 & 462 & -92 \\
\hline Central America & -190 & 1181 & -505 & -46 & -46 & 0 & -4 & -5 & 35 & -76 \\
\hline Caribbean & -153 & 61 & -84 & 27 & 26 & -1 & -2 & -4 & 40 & -10 \\
\hline LAC Subtotal & 3512 & 5609 & 3402 & 2484 & 2480 & -1 & 20 & 14 & 3128 & -685 \\
\hline South Africa & -1677 & -529 & -543 & -158 & -403 & -91 & 17 & -321 & 3 & -84 \\
\hline Sub-Saharan Africa & 322 & 308 & -127 & -253 & -249 & -203 & 3 & -196 & 3 & -54 \\
\hline SADC & 491 & 132 & 1151 & 265 & 508 & 380 & -3 & 618 & -11 & -105 \\
\hline \multicolumn{11}{|l|}{ Sub-Saharan Africa } \\
\hline Subtotal & -864 & -89 & 481 & -146 & -144 & 86 & 17 & 101 & -5 & -243 \\
\hline \multicolumn{11}{|l|}{ Middle East and } \\
\hline North Africa & -1115 & -532 & 5090 & 704 & 1119 & 1 & 1120 & 1540 & 21 & -460 \\
\hline South-East Europe & -699 & -162 & -179 & -78 & -82 & -2 & -25 & -31 & -7 & -44 \\
\hline Rest of World & 1087 & 1502 & 106 & -49 & -52 & 14 & 26 & 37 & 3 & -92 \\
\hline \multicolumn{11}{|l|}{ Developing } \\
\hline Countries & 28085 & 22216 & 35252 & 15557 & 15834 & -23 & 580 & 830 & 2906 & 11969 \\
\hline World & 90139 & 41244 & 17222 & 8001 & 8010 & -204 & -683 & -882 & 496 & 8304 \\
\hline
\end{tabular}

Source: GTAP simulations. 
more than half of total allocative welfare effects. In the case of sub-Saharan African countries, the allocative welfare effect generated by liberalization of the cereals sector accounts for almost 90 per cent of total welfare gain due to allocative effects. Removal of agricultural barriers between developing countries generates welfare gains due to reallocation effects in developing countries of $\$ 10.8$ billion (almost 51 per cent of total reallocation welfare gains), compared with gains of $\$ 10.5$ billion (49 per cent of total reallocation welfare gains) from reform in the manufacturing sector. However, if the Other Asia country group is excluded, allocative gains due to reform in agricultural sectors fall to $\$ 4$ billion, which represents less than half of the gains due to reform in manufacturing sectors.

The European Union, North America, Japan and Other Developed countries experience welfare losses derived from negative terms-of-trade effects in the manufacturing (in particular metallic and nonmetallic manufactures, and electronics) and service sectors (essentially business and transport services). This stems from a fall in the price of exports of these goods. Because terms-of-trade effects sum to zero globally, these negative effects are correspondingly positive for developing countries through lower import prices.

The benefits from regional integration are less substantial, although positive nonetheless. Results also indicate that regional integration implies welfare losses for nonintegrating regions. Regional integration is a good response to trade blocs forming elsewhere. It may be less than optimal but better than being left out altogether.

Liberalization within developing Asia (China, Other Asia, India, Other South Asia and ASEAN) generates gains in these counties of $\$ 13.3$ billion. Gains to Asia (i.e. excluding Japan) from South-South liberalization are
$\$ 26.3$ billion, illustrating the links between Asia and other developing countries.

The benefits from a Latin American free trade area are less than from South-South liberalization. The LAC region is also the only region that would benefit more on aggregate from North-South than from South-South trade liberalization, although this qualification does not hold for Mexico. The latter is better off by $\$ 1.2$ billion in the South-South scenario but worse off by $\$ 1.1$ billion in the NorthSouth scenario. Mexico's welfare gains are due essentially to positive allocative effects in the motor-vehicle, electronics and textiles sectors. Losses come from negative terms-of-trade welfare effects in these same sectors. Central America and the Caribbean lose $\$ 0.6$ billion from South-South liberalization and gain $\$ 1.2$ billion from North-South liberalization due to positive terms-of-trade effects. Regional integration only slightly increases their welfare ( $\$ 0.075$ billion).

The gains to sub-Saharan Africa from trade liberalization within the region amount to less than $\$ 0.1$ billion. North-South trade liberalization would generate losses of almost $\$ 0.1$ billion. Benefits to Africa from SouthSouth liberalization are the highest $\$ 0.5$ billion) of all the scenarios, although they remain modest in absolute terms. These gains are driven by SADC countries (excluding South Africa). The bulk of the gains come from allocative efficiency gains encountered in the cereals sector, and to a much lesser extent in the textiles, apparel and leather sectors. Terms-of-trade effects are either negative or almost insignificant in all sectors. Simulations indicate that sub-Saharan Africa would gain substantially by trade reform only if it occurs within a context of preferential and exclusive access to Northern markets. ${ }^{5}$ In that context, welfare gains could reach $\$ 5.6$ billion and almost at no cost to developed and other developing countries.

\footnotetext{
5 See Fugazza and Peters (2005) for a detailed presentation.
} 
The gains to Middle Eastern and North African countries as a group are the highest in the South-South trade liberalization scenario ( $\$ 5$ billion). These countries would face welfare losses in the North-South liberalization scenario. Regional integration would remain a desirable option, although it would be worth only one fourth of the welfare gains obtained in the South-South trade liberalization scenario.
The conclusion here is that, with the exception of Latin America, developing countries are missing out if they follow a regional approach. However, Central American and Caribbean countries would benefit more from North-South liberalization than from any other liberalization scenario.

Table 7. Change in value of exports relative to base (Thousands of US dollars and percentages)

\begin{tabular}{|c|c|c|c|c|c|c|c|c|c|c|}
\hline & $\begin{array}{c}\text { Initial } \\
\$ 000\end{array}$ & $\begin{array}{c}\text { North } \\
\%\end{array}$ & $\begin{array}{l}\text { South- } \\
\text { South } \\
\%\end{array}$ & $\begin{array}{c}\text { Southern } \\
\text { RTAs(1) } \\
\%\end{array}$ & $\begin{array}{c}\text { Southern } \\
\text { RTAs(2) } \\
\%\end{array}$ & $\begin{array}{c}\text { SSA } \\
\%\end{array}$ & $\begin{array}{c}\text { MENA } \\
\%\end{array}$ & $\begin{array}{c}\text { SSA+ } \\
\text { MENA } \\
\%\end{array}$ & $\begin{array}{c}\text { LAC } \\
\%\end{array}$ & $\begin{array}{c}\text { Asia } \\
\%\end{array}$ \\
\hline European Union & 2674109 & 1 & 0 & 0 & 0 & 0 & 0 & 0 & 0 & 0 \\
\hline United States & 888812 & 5 & -2 & -1 & -1 & 0 & 0 & 0 & 0 & 0 \\
\hline North America & 267956 & 4 & 0 & 0 & 0 & 0 & 0 & 0 & 0 & 0 \\
\hline Japan & 453022 & 7 & -1 & -1 & -1 & 0 & 0 & 0 & 0 & -1 \\
\hline Other developed & 260869 & 6 & -1 & 0 & 0 & 0 & 0 & 0 & 0 & 0 \\
\hline Subtotal & 4544768 & 3 & -1 & 0 & 0 & 0 & 0 & 0 & 0 & 0 \\
\hline China & 481761 & 3 & 10 & 7 & 7 & 0 & 0 & 0 & 0 & 7 \\
\hline India & 61126 & 2 & 34 & 23 & 23 & 0 & 0 & 0 & 0 & 23 \\
\hline Other Asia & 319080 & 2 & 9 & 6 & 6 & 0 & 0 & 0 & 0 & 6 \\
\hline Other South Asia & 28837 & 3 & 25 & 23 & 23 & 0 & 0 & 0 & 0 & 23 \\
\hline ASEAN & 447936 & 1 & 6 & 4 & 4 & 0 & 0 & 0 & 0 & 4 \\
\hline Asia Subtotal & 1338740 & 2 & 10 & 7 & 7 & 0 & 0 & -1 & 0 & 7 \\
\hline Mexico & 165571 & 0 & 5 & 2 & 2 & 0 & 0 & 0 & 2 & 0 \\
\hline Andean & 52762 & 2 & 2 & 4 & 4 & 0 & 0 & 0 & 5 & 0 \\
\hline Mercosur & 102822 & 5 & 12 & 7 & 7 & 0 & 0 & 0 & 7 & 0 \\
\hline Rest of Latin America & 55085 & 2 & 7 & 5 & 5 & 0 & 0 & 0 & 5 & 0 \\
\hline Central America & 26970 & 5 & 5 & 3 & 3 & 0 & 0 & 0 & 3 & 0 \\
\hline Caribbean & 7484 & 1 & 11 & 2 & 2 & 0 & 0 & 0 & 2 & 0 \\
\hline LAC Subtotal & 410695 & 2 & 7 & 4 & 4 & 0 & 0 & 0 & 4 & 0 \\
\hline South Africa & 44822 & -1 & 12 & 4 & 2 & 3 & 0 & 4 & 0 & 0 \\
\hline Sub-Saharan Africa & 23553 & 3 & 7 & 4 & 4 & 4 & 0 & 4 & 0 & 0 \\
\hline SADC & 39747 & 1 & 8 & 3 & 2 & 2 & 0 & 3 & 0 & 0 \\
\hline \multicolumn{11}{|l|}{ Sub-Saharan Africa } \\
\hline Subtotal & 108122 & 1 & 9 & 4 & 2 & 3 & 0 & 12 & 0 & 0 \\
\hline \multicolumn{11}{|l|}{ Middle East and } \\
\hline North Africa & 315127 & 0 & 8 & 4 & 4 & 0 & 4 & 5 & 0 & 0 \\
\hline South-East Europe & 36444 & 0 & -1 & 0 & 0 & 0 & 0 & 0 & 0 & 0 \\
\hline Rest of World & 156334 & 2 & 0 & 0 & 0 & 0 & 0 & 0 & 0 & 0 \\
\hline \multicolumn{11}{|l|}{ Developing } \\
\hline Countries & 6717451 & 2 & 2 & 2 & 2 & 0 & 0 & 0 & 0 & 1 \\
\hline World & 6910229 & 2 & 2 & 2 & 1 & 0 & 0 & 0 & 0 & 1 \\
\hline
\end{tabular}

Source: GTAP simulations. 


\section{Exports}

Trade negotiators seem primarily concerned about exports. In this respect South-South trade reform is estimated to be beneficial for most of the developing country regions, as shown in table 7 . The exceptions to a very small extent are the Andean Pact and Central American countries, whose exports remain almost unchanged. In most cases the gains in export revenues from SouthSouth liberalization far exceed the benefits of further access to Northern markets. However, aggregated results for developing countries are pretty similar in both scenarios. Most notable in this respect is India, which faces significant barriers in exporting textiles, apparel and nonmetallic manufactures (paper products, chemicals, rubber and plastics) to other Asian countries. In most instances the gains from a regional RTA are reduced. This is particularly true for sub-Saharan African countries. For example, South African exports increase 12 per cent following South-South liberalization, as against 3 per cent with regional integration. Sub-Saharan African exports increase 9 per cent following South-South liberalization, as against 3 per cent with regional integration. In addition, each RTA leads to nil or even negative trade effects in many non-members. Three simultaneous RTAs do not provide much additional benefit either. Indeed, there are significant trade diversion effects, except for the Asian region countries, which obtain the same rise in exports as with Asian regional integration alone.

When looking at the changes in the destination of exports from the various regions and country groups, the results indicate that South-South liberalization would significantly change the current geography of trade, while North-South liberalization would affect it only slightly. With South-South trade liberalization, interregional exports within developing regions increase dramatically. For instance, exports from the ACP region to the LAC region increase by 60 per cent and those to the SSA region by 69 per cent. Exports from the SSA region to the ACP region increase by 56 per cent. Exports among developing countries increase at the expense of exports directed to developed regions. We also observe that intra-regional trade increases for all developing countries except for some sub-Saharan African and Latin American countries.

\section{Tariff revenues}

Many developing countries are concerned that trade liberalization will have a significant adverse impact on government revenues because tariff revenues make a substantial contribution to public revenue. ${ }^{6}$ Eliminating tariffs altogether implies that tariff revenues would be reduced to zero. In addition, although partial tariff cuts may lead to a rise in tariff revenue because of the increase in trade flows associated with liberalization, preferential agreements lead to a switch in supplies away from the taxable source, reducing revenues even further. Many developing countries would have to raise taxes on income, profits, capital gains, property, labour and consumption or increase non-tax revenues to compensate. Broad-based taxes have the advantage of being less distortionary, but they are not as simple to collect as tariff revenues, particularly for countries with poorly developed administrative systems. The simulation results indicate that the SouthSouth scenario would result in an estimated 62 per cent decline in developing country tariff revenues, with regional averages of 63 , 55, 60 and 73 per cent in Asia, Latin America, Africa and MENA respectively (see table 8 ). The global average tariff revenue reduction is 34 per cent, from $\$ 231$ billion to $\$ 151$ billion. Not surprisingly, the regional scenarios result in a lesser impact in the developing country regions.

\footnotetext{
${ }^{6}$ In the GTAP framework, changes in tariff revenues and their impact on the economy are reflected in welfare analysis. That is to say that those losses in tariff revenues should not be compared to welfare results as the latter account for the former.
} 
Table 8. Change in tariff revenues relative to base

(Thousands of US dollars and percentages)

\begin{tabular}{|c|c|c|c|c|c|c|c|c|c|c|}
\hline & $\begin{array}{c}\text { Initial } \\
\$ 000\end{array}$ & $\begin{array}{c}\text { North } \\
\%\end{array}$ & $\begin{array}{l}\text { South- } \\
\text { South } \\
\%\end{array}$ & $\begin{array}{c}\text { Southern } \\
\text { RTAs(1) } \\
\%\end{array}$ & $\begin{array}{c}\text { Southern } \\
\text { RTAs(2) } \\
\%\end{array}$ & $\begin{array}{c}\text { SSA } \\
\%\end{array}$ & $\begin{array}{c}\text { MENA } \\
\%\end{array}$ & $\begin{array}{c}\text { SSA+ } \\
\text { MENA } \\
\%\end{array}$ & $\begin{array}{c}\text { LAC } \\
\%\end{array}$ & $\begin{array}{c}\text { Asia } \\
\%\end{array}$ \\
\hline European Union & 54537 & -100 & -11 & -6 & -6 & 0 & -1 & -1 & -1 & -4 \\
\hline United States & 32331 & -100 & -18 & -12 & -12 & 0 & 0 & -1 & -1 & -11 \\
\hline North America & 3191 & -98 & -8 & -6 & -6 & 0 & 0 & 0 & -2 & -4 \\
\hline Japan & 23541 & -100 & -8 & -6 & -6 & 0 & 0 & 0 & -1 & -5 \\
\hline Other developed & 9125 & -100 & -9 & -6 & -6 & 0 & 0 & 0 & -1 & -5 \\
\hline Subtotal & 122726 & -100 & -12 & -8 & -7 & 0 & 0 & -1 & -1 & -6 \\
\hline China & 26281 & 5 & -51 & -33 & -32 & 0 & -4 & -4 & 0 & -28 \\
\hline India & 3422 & 1 & -55 & -19 & -18 & -1 & -1 & -2 & 0 & -16 \\
\hline Other Asia & 18617 & -1 & -76 & -57 & -57 & 0 & -1 & -1 & 0 & -56 \\
\hline Other South Asia & 2106 & 2 & -35 & -15 & -14 & 0 & -1 & -2 & 0 & -13 \\
\hline ASEAN & 21343 & 3 & -71 & -59 & -58 & 0 & -1 & -2 & 0 & -57 \\
\hline Asia Subtotal & 71769 & 2 & -63 & -45 & -45 & 0 & -2 & -2 & 0 & -43 \\
\hline Mexico & 1676 & -3 & -59 & -56 & -56 & 0 & 0 & 0 & -48 & -8 \\
\hline Andean & 1991 & 2 & -58 & -35 & -35 & 0 & 0 & 0 & -22 & -13 \\
\hline Mercosur & 10394 & 6 & -68 & -40 & -39 & 0 & 0 & 0 & -24 & -16 \\
\hline Rest of Latin America & 2278 & 2 & -32 & -33 & -33 & 0 & 0 & 0 & -32 & -2 \\
\hline Central America & 1757 & 6 & -8 & -17 & -17 & 0 & 0 & 0 & -16 & -1 \\
\hline Caribbean & 429 & 0 & -26 & -18 & -18 & 0 & 0 & 0 & -17 & -2 \\
\hline LAC Subtotal & 18524 & 2 & -55 & -37 & -37 & 0 & 0 & 0 & -26 & -11 \\
\hline South Africa & 962 & 1 & -70 & -50 & -45 & -24 & 0 & -30 & -1 & -19 \\
\hline Sub-Saharan Africa & 1161 & -2 & -28 & -17 & -14 & -12 & 0 & -15 & 0 & -2 \\
\hline SADC & 2123 & 3 & -74 & -48 & -42 & -31 & -1 & -38 & 0 & -11 \\
\hline \multicolumn{11}{|l|}{ Sub-Saharan Africa } \\
\hline Subtotal & 4247 & 0 & -60 & -40 & -35 & -24 & 0 & -30 & 0 & -10 \\
\hline \multicolumn{11}{|l|}{ Middle East and } \\
\hline North Africa & 8702 & -1 & -73 & -36 & -31 & 0 & -22 & -27 & 0 & -9 \\
\hline South-East Europe & 1128 & -2 & -4 & -2 & -2 & 0 & 0 & -1 & 0 & -2 \\
\hline Rest of World & 4071 & 4 & -9 & -5 & -5 & 0 & 0 & -1 & 0 & -5 \\
\hline \multicolumn{11}{|l|}{ Developing } \\
\hline Countries & 103242 & 4 & -62 & -43 & -42 & -1 & -3 & -5 & -5 & -33 \\
\hline World & 231165 & -32 & -34 & -23 & -23 & -1 & -2 & -3 & -2 & -18 \\
\hline
\end{tabular}

Source: GTAP simulations.

\section{Sectoral effects}

Policymakers are interested in individual sectors, as some sectors are regarded as sensitive and greater weight is attached to their output, employment or exports. In addition, it is more difficult to move labour out of some sectors (e.g. fisheries) than others, or there may be limits to expansion in other sectors due to resource (e.g. water) or environmental constraints.

The major impacts of liberalization are felt in those sectors where large trade flows are coupled with significant protection levels. These are typically agriculture, textiles and motor vehicles. This also holds to a large extent for South-South liberalization. 
However, compared with North-South liberalization, South-South liberalization is accompanied by a larger impact in manufacturing sectors relative to agricultural products sectors.

The largest percentage increases in exports among the developing countries occur in cereals in Asia, dairy products in Asia and Latin America, livestock in Asia, vegetable oils in Asia and Africa, and motor vehicles in Asia (see annex table A2). The increase can reach more than 600 per cent, as in the case of the vegetal oils sector in the Other Asia group. However, big increases often occur in countries that initially had only small shares of world exports and as a consequence do not modify the geography of sectoral trade dramatically. The largest percentage decrease in exports (-27 per cent) occurs in apparel for the MERCOSUR country group. Otherwise, and as far as merchandises exports are concerned, there are only a few cases where more than 15 per cent of the initial exports are eliminated.

As to developed countries, SouthSouth trade liberalization causes decreases in exports in almost all merchandise sectors. Decreases can be as much as 98 per cent, as in the case of cereals in Japan. Developed countries' export market shares fall significantly in the agricultural products and apparel sectors. Drops in market shares are more pronounced for the United States and Japan than for the European Union.

In terms of the necessary adjustments, perhaps a better indication can be gauged from changes in output. These are somewhat arbitrary, as they depend on the aggregation of sectors. Broader aggregation leads to smaller percentage changes. The largest estimated percentage falls in output from South-South liberalization occur in the Other Asia cereals and vegetable oils sectors (see appendix table A3). Output falls by 56 per cent in the cereals sector and by 76 per cent in the vegetable oil sector. However, both sectors initially represented only small shares of total output, meaning that inherent adjustment costs are likely to be contained. Bigger concerns could be raised for sub-Saharan African countries, where output in cereals sectors falls by 13 per cent when it initially represented almost 5 per cent of output. This also holds for the textiles, apparel and leather sectors, where output falls on average by more than 15 per cent when it initially represented more than 2 per cent of total output. Another result is that output in textiles and apparels falls by more than 16 per cent in MENA countries, when it initially represented almost 1.5 per cent of the region's output.

Changes in value terms highlight the main differences between North-South and South-South liberalization in terms of production structure (see table 9). First, looking at developing countries as a group, production in agricultural goods increases under both scenarios. However, it is more than five times higher when access to Northern markets is liberalized. Second, and perhaps more importantly, production in manufacturing goods falls for all developing country groups except Asian countries in the North-South liberalization scenario, while it increases or decreases to a much lesser extent in the case of SSA countries in the SouthSouth liberalization scenario. While NorthSouth trade liberalization gives better access to developing countries' products, especially in agricultural product markets, South-South trade liberalization also gives access to the unexploited manufactures markets. This result becomes highly relevant when assessing the respective development potential of each scenario. Third, production in services increases in all developing countries under both scenarios. On aggregate, the increase is significantly higher under the South-South trade liberalization scenario, plus $\$ 130$ billion against $\$ 95$ billion under the North-South trade liberalization scenario. 
Table 9. Changes in output values by economic sector

(Thousands of US dollars)

\begin{tabular}{|c|c|c|c|c|c|c|c|c|c|}
\hline & & Dev & Dvg & Asia & LAC & MENA & SSA & SEE & ROW \\
\hline \multirow{3}{*}{$\mathrm{N}-\mathrm{S}$} & Agri & -194210 & 178269 & 102381 & 58262 & 10362 & 7263 & 4075 & 21303 \\
\hline & Manu & 41409 & 21037 & 35985 & -11360 & -1900 & -1687 & -1100 & 631 \\
\hline & Ser & 22725 & 95129 & 53678 & 35321 & 4341 & 1790 & 628 & 8034 \\
\hline \multirow{3}{*}{ S-S } & Agri & -19650 & 32219 & 6524 & 22960 & 5228 & -2494 & 46 & 245 \\
\hline & Manu & -28932 & 82595 & 65172 & 6016 & 11906 & -500 & -452 & -2057 \\
\hline & Ser & 6418 & 129940 & 77965 & 31466 & 17529 & 2979 & 240 & 929 \\
\hline
\end{tabular}

Source: GTAP simulations.

A more detailed analysis of SouthSouth liberalization results reveals that in value terms the most significant falls in output in developing countries are in electronics in Other Asian countries ( $\$ 10.5$ billion), textiles in the MENA region ( $\$ 7.9$ billion) and nonmetallic manufactures in China (-\$3.7). Increases in non-metallic manufactures production in MENA ( $\$ 15$ billion), Other Asia ( $\$ 10.5$ billion) and ASEAN ( $\$ 9.3$ billion) cover the fall in production in China, India $(-\$ 1.2$ billion) and some developed countries. Although non-metallic manufactures include products such as chemicals whose production requires high skill and technology intensity, it is reasonable to think that MENA countries move part of their production resources from textiles towards non-metallic manufactures that are also labour-intensive, such as mineral products or wood and paper. The falls in production in electronics in Other Asian countries is matched by an increase in all developed countries, in particular in the European Union ( $\$ 4.2$ billion), Japan ( $\$ 3.9$ billion) and the United States ( $\$ 3$ billion), and in China ( $\$ 4.3$ billion) and Mexico ( $\$ 2.7$ billion) as far as developing countries are concerned. Imports into developed countries' markets initially originating from Other Asia are supplanted by imports from other developed countries and Mexico in the case of the United States. China also exports less to those markets but more to the ASEAN and Mexican markets. In addition, Other Asia and ASEAN exports to China are expected to surge. In the North-South liberalization scenario, only Mexico is able to export significantly more non metallic manufactures, once again thanks to its access to the US market. All other developing country exports fall, sometimes quite substantially, essentially due to a reallocation of productive resources towards agricultural products.

There are also significant drops in output of textiles (-\$12.1 billion) and apparel ( $\$ 7.5$ billion) in the developed countries. Output drops translate into conspicuous falls in exports. There are also important reductions in production, and to a large extent in exports, in the Middle East and North Africa, MERCOSUR and Mexico. China, India, Other Southern Asia and Other Asia fill in the production and export gap for textiles and to a large extent for apparel. This represents a significant shift in textile production to developing countries. However, the shift in apparel manufacture is smaller. Textile production is generally more capitalintensive than apparel, but the technological requirements are not so demanding as to put it out of reach of mid-range developing countries. Perhaps the most significant shift occurs in China, which imports additional textiles (but not apparel) from Other Asia (Republic of Korea and Taiwan, Province of China). The imported textiles are used to produce apparel that is then exported to MENA. Some countries show an increase in output in the textile sector but at best a small 
increase in the downstream processing stage. For example, countries belonging to the Other Asia group also expand their textile sector, but only slightly increase output of apparel. By contrast, in Central America, output of apparel expands almost six times as much as output of textiles, reflecting differential protection on these products. In Other South Asia, the same pattern appears, although output in apparel increases only twice as much as that of textiles. North-South liberalization gives substantial differences in the results as far as export destinations are concerned. In particular, China is found to cover most of the exports to developed countries markets. In the South-South scenarios, exports to these markets originate from other developing countries and not from China, whose exports flow to other developing countries.

Another highly protected sector is motor vehicles, parts and components. The average applied tariff imputed from the GTAP database is 3.3 per cent globally, but 11 per cent on developing country imports. ${ }^{7}$ Among the developing countries, the major exporters are Other Asia, Mexico and Mercosur. These countries operate assembly industries with a high proportion of imported components. For example, Mexican imports in this sector are valued at 75 per cent of its exports. Following South-South liberalization, exports from Other Asia ( $\$ 5.8$ billion), Mercosur $(\$ 4.7$ billion), China ( $\$ 4.4$ billion), Mexico ( $\$ 2.4$ billion), and ASEAN ( $\$ 1.7$ billion) displace those from the United States ( $\$ 3.9$ billion), Europe ( $\$ 3.8$ billion), and Japan ( $\$ 2.5$ billion). In the North-South liberalization scenario, all developed countries would see their exports increase, in particular Japan ( $\$ 13.1$ billion), while developing countries' exporters would all face decreases, with the exception of Other Asia countries. Export patterns closely reflect production patterns.

\section{CONCLUDING REMARKS AND IMPLICATIONS}

A feature of South-South trade is that developing country economies are, by definition, at a similar stage of development, and the levels of competitiveness are somewhat similar. Developing countries need be less concerned about being swamped by high-quality or cheap imports with which it is difficult to compete. Nonetheless, many developing countries appear concerned about China, which has the potential to be competitive in many markets, particularly textiles and apparel, sectors where many other developed countries see themselves competing. These fears appear to be founded, especially in the context of North-South trade liberalization. Results presented here also suggest that if China were to expand into these sectors, it would vacate others, such as non-metallic manufactures, agriculture and services. In addition, a surge in Chinese exports implies a similar increase in imports. For developing countries, an important question is where these additional imports are likely to come from. In the North-South liberalization scenario, they would principally come from developed countries. On the contrary, in the South-South liberalization scenario, they would come from other developing countries. Principal import sources would be other Asian countries and MERCOSUR.

A limitation of regional agreements among developing countries is that the economies are not so different, and the potential gains stemming from differing relative factor endowments and costs are not forthcoming. Many countries within Africa have low labour and high capital costs, and the gains from trading with each other are limited and even contrasting. Contrasting

\footnotetext{
7 This estimate is imputed from the GTAP database, and may not reflect actual revenues collected.
} 
results are evident when comparing the effects of North-South and South-South liberalization. For individual developing countries, obtaining further access to developed countries markets is particularly beneficial if preferential access is obtained, but this is at the expense of other countries that are shut out.

Some limitations ought to be noted when drawing inferences from this analysis. Missing from the modelling are several factors that are important in trade negotiations, such as investment and competition policies, SPS, TBT, services and various so-called non-trade concerns. In addition, there are deficiencies in the model, in both the structure and the data. For example, no dynamic gains are calculated here. These include the increase in productivity resulting from enhanced competition and new technologies. These gains may outweigh static gains. Also ignored are the benefits of increasing returns to scale, which imply that specialization of production leads to productivity gains. Monopolistic competition is also ignored (also in foreign markets, where the power of large marketing chains often drives down prices received by producers in developing countries). Nor is consideration given to adjustment costs. These are difficult to measure, but real enough, even though they occur only once whereas the benefits accrue every year. Labour is assumed to be fixed, whereas in reality there is scope for drawing unemployed or underemployed labour into the workforce, especially in developing countries. This makes a significant difference to the welfare effects, reinforcing both gains and losses.

The inclusion of preferential tariffs in this database makes its use desirable, but it also remains relatively untested. There is uncertainty about the utilization of preferences and how quota rents should be allocated. There is also scope for debate about the method used to convert from specific to ad valorem tariffs, as well as the weight given to inquota versus outquota tariff rates, or the use of simple versus trade weights to aggregate across tariff lines. Data on services protection are missing for most countries. Furthermore, there are bound to be errors and omissions in databases of the size used here.

These qualifications affect the magnitude of the estimated gains and losses, but apply across all scenarios. The ranking of the outcomes are unlikely to change by addressing these concerns, and hence the conclusions drawn from the results are likely to be relatively robust.

Given these estimated potential impacts on welfare, trade flows, government revenues and output, and keeping in mind possible drawbacks and limitations of the methodology adopted in this paper, what can be said about a developing country's optimal strategy? The simulations undertaken here show that the largest overall gains would be obtained with trade liberalization. However, some regions like sub-Saharan Africa would be net losers, calling for the establishment of some redistributive schemes able to countervail possible adjustment issues. Various studies highlight the existence of supply capacity constraints in most of the countries of that region, which may indicate a plausible way forward in a context of international redistribution of trade liberalization gains. However, the simulations also show that there are potentially large gains for developing countries from South-South trade, though capturing these gains would still require substantial reform, and this has invariably proved difficult to implement. Nevertheless, the promotion of South-South trade may appear to be a redistributive instrument, possibly qualifying a desirable sequencing of overall trade liberalization. The recent revival of the GSTP programme could be a very efficient means of realizing these gains and establishing de facto such a sequencing. 


\section{REFERENCES}

Anderson K., W. Martin and D. van der Mensbrugghe (2005). 'Doha Merchandise Trade Reform: What's at stake for developing countries?', CEPR Discussion Paper No. 5156.

Francois J., B. McDonald and H. Nordström (1996). 'Liberalization and Capital Accumulation in the GTAP Model', GTAP Technical Paper No.7.

Fugazza M. and F. Robert-Nicoud (2006). 'Can South-South trade liberalization stimulate NorthSouth trade?', Journal of Economic Integration, 21(2), pp. 62-90.

Fugazza M. and R. Peters (2005). 'Deepening and Broadening Preferential Access for Sub-Saharan Africa: Results from General Equilibrium Analysis.' UNCTAD note prepared for the Report of the Commission for Africa, 2005.

Fujita, M., P. Krugman and A.J.Venables (1999). The Spatial Economy: Cities, Regions, and International Trade. MIT Press, Cambridge and London.

Hertel, T., E. Ianchovichina and B. McDonald. (1997) 'Multi-region general equilibrium modeling', in Francois, J. and K. Reinert (Eds), Applied Methods for Trade Policy Analysis, Cambridge University Press, United Kingdom.

GTAP (Global Trade Analysis Project) (2005). http://www.gtap.org.

Puga, D., and A.J. Venables (1998). 'Trading Arrangements and Industrial Development', The World Bank Economic Review 12(2), pp. 221-49.

Puga, D., and A. J. Venables (1999). 'Agglomeration and Economic Development: Import Substitution vs. Trade Liberalization.' Economic Journal 109(455), pp. 292-311.

UNCTAD (2003). Back to Basics: Market Access Issues in the Doha Agenda, UNCTAD/DITC/TAB/ Misc.9, Sales No. E.03.II.D.4, Geneva.

Venables, A.J (2003). 'Winners and losers from regional integration agreements.' Economic Journal 113, pp. 747-761.

WITS/TRAINS (2004). Database on International Trade and Tariffs, UNCTAD/World Bank, Geneva and Washington, DC. 
Table A1. Decomposition of welfare effects

A. Contribution to Welfare of changes in terms of trade (thousands of US dollars)

\begin{tabular}{|c|c|c|c|c|c|c|c|c|c|}
\hline & $\begin{array}{l}\text { North- } \\
\text { South }\end{array}$ & $\begin{array}{l}\text { South- } \\
\text { South }\end{array}$ & $\begin{array}{c}\text { Southern } \\
\text { RTAs(1) }\end{array}$ & $\begin{array}{c}\text { Southern } \\
\text { RTAs(2) }\end{array}$ & SSA & MENA & $\begin{array}{l}\text { SSA+ } \\
\text { MENA }\end{array}$ & LAC & Asia \\
\hline European Union & -14577 & -7149 & -3216 & -3411 & -149 & -665 & -1008 & -636 & -1754 \\
\hline United States & -2869 & -6069 & -2174 & -2214 & -30 & -196 & -264 & -1039 & -889 \\
\hline North America & -2963 & -7 & -136 & -134 & 4 & 26 & 32 & -11 & -156 \\
\hline Japan & -1972 & -3611 & -1730 & -1764 & -24 & -207 & -264 & -243 & -1253 \\
\hline Other developed & -939 & -705 & -415 & -411 & 0 & 24 & 27 & -6 & -431 \\
\hline Subtotal & -23320 & -17541 & -7671 & -7934 & -199 & -1018 & -1477 & -1935 & -4483 \\
\hline China & 6747 & 2121 & -382 & -428 & -29 & -148 & -225 & -93 & -111 \\
\hline India & 607 & -2629 & -2278 & -2308 & -27 & -95 & -152 & -14 & -2142 \\
\hline Other Asia & 3183 & 9397 & 6859 & 6829 & -27 & -167 & -225 & -143 & 7171 \\
\hline Other South Asia & 258 & -750 & -715 & -720 & -3 & -33 & -41 & -2 & -678 \\
\hline ASEAN & 5822 & 6709 & 1331 & 1300 & -22 & -91 & -146 & 3 & 1448 \\
\hline Asia Subtotal & 16617 & 14848 & 4815 & 4673 & -108 & -534 & -789 & -249 & 5688 \\
\hline Mexico & -924 & -112 & 580 & 581 & 2 & 6 & 9 & 624 & -53 \\
\hline Andean & 320 & 472 & -389 & -388 & 4 & 28 & 32 & -222 & -198 \\
\hline Mercosur & 3585 & 1579 & 1131 & 1126 & -7 & -10 & -22 & 1420 & -291 \\
\hline Rest of Latin America & 724 & -127 & 250 & 250 & -1 & 0 & -1 & 336 & -87 \\
\hline Central America & 825 & -275 & -68 & -68 & 0 & -2 & -1 & -21 & -46 \\
\hline Caribbean & 41 & -7 & 7 & 6 & 0 & -1 & -2 & 5 & 3 \\
\hline LAC Subtotal & 4571 & 1530 & 1511 & 1507 & -2 & 21 & 15 & 2142 & -672 \\
\hline South Africa & -278 & -543 & 0 & -41 & 11 & 16 & -14 & 7 & -34 \\
\hline Sub-Saharan Africa & 289 & -327 & -146 & -152 & -123 & 3 & -126 & 4 & -29 \\
\hline SADC & 121 & 979 & 268 & 487 & 404 & -4 & 616 & -11 & -125 \\
\hline \multicolumn{10}{|l|}{ Sub-Saharan Africa } \\
\hline Subtotal & 132 & 109 & 122 & 294 & 292 & 15 & 476 & 0 & -188 \\
\hline \multicolumn{10}{|l|}{ Middle East and } \\
\hline North Africa & -225 & 893 & 1282 & 1523 & 7 & 1510 & 1759 & 30 & -266 \\
\hline South-East Europe & -3 & -72 & -21 & -23 & -1 & -16 & -18 & -1 & -3 \\
\hline Rest of World & 1891 & -125 & -176 & -181 & 8 & 18 & 22 & -5 & -198 \\
\hline \multicolumn{10}{|l|}{ Developing } \\
\hline Countries & 22983 & 17183 & 7533 & 7793 & 196 & 1014 & 1465 & 1917 & 4361 \\
\hline World & -337 & -358 & -138 & -141 & -3 & -4 & -12 & -18 & -122 \\
\hline
\end{tabular}


Table A1. Decomposition of welfare effects (continued)

B. Contribution to welfare of allocative effects (thousands of US dollars)

\begin{tabular}{|c|c|c|c|c|c|c|c|c|c|}
\hline & $\begin{array}{l}\text { North- } \\
\text { South }\end{array}$ & $\begin{array}{l}\text { South- } \\
\text { South }\end{array}$ & $\begin{array}{l}\text { Southern } \\
\text { RTAs(1) }\end{array}$ & $\begin{array}{l}\text { Southern } \\
\text { RTAs(2) }\end{array}$ & SSA & MENA & $\begin{array}{l}\text { SSA+ } \\
\text { MENA }\end{array}$ & LAC & Asia \\
\hline European Union & 13495 & -1662 & -523 & -561 & -28 & -178 & -243 & -219 & -93 \\
\hline United States & 1638 & -147 & 284 & 285 & 1 & -5 & -2 & -70 & 355 \\
\hline North America & 3344 & -4 & 12 & 13 & 1 & 5 & 7 & 0 & 7 \\
\hline Japan & 18234 & -308 & -127 & -132 & -3 & -36 & -44 & -4 & -86 \\
\hline Other developed & 2803 & -183 & -55 & -59 & -3 & -13 & -19 & 6 & -45 \\
\hline Subtotal & 39514 & -2304 & -409 & -454 & -32 & -227 & -301 & -287 & 138 \\
\hline China & 2059 & 1373 & 800 & 795 & -7 & -27 & -39 & -2 & 838 \\
\hline India & 108 & 2064 & 784 & 766 & -20 & -40 & -80 & -14 & 848 \\
\hline Other Asia & -68 & 8197 & 6364 & 6360 & -5 & -20 & -29 & -65 & 6396 \\
\hline Other South Asia & -16 & 611 & 543 & 542 & -1 & -8 & -10 & 1 & 552 \\
\hline ASEAN & 381 & 1137 & 124 & 120 & -2 & -14 & -20 & -11 & 151 \\
\hline Asia Subtotal & 2464 & 13382 & 8615 & 8583 & -35 & -109 & -178 & -91 & 8785 \\
\hline Mexico & -390 & 1147 & 271 & 271 & 0 & 0 & 0 & 269 & 3 \\
\hline Andean & 45 & 79 & -91 & -91 & 0 & 3 & 3 & -69 & -24 \\
\hline Mercosur & 590 & 503 & 527 & 525 & -2 & -3 & -6 & 573 & -44 \\
\hline Rest of Latin America & 106 & 131 & 106 & 106 & 0 & 0 & -1 & 126 & -19 \\
\hline Central America & 158 & -87 & 5 & 5 & 0 & -1 & -1 & 21 & -15 \\
\hline Caribbean & -19 & -13 & -9 & -9 & 0 & 0 & 0 & -5 & -4 \\
\hline LAC Subtotal & 490 & 1760 & 809 & 807 & -2 & -1 & -5 & 915 & -103 \\
\hline South Africa & -248 & 267 & -135 & -293 & -96 & -1 & -257 & -3 & -34 \\
\hline Sub-Saharan Africa & 21 & 167 & -116 & -106 & -84 & 0 & -75 & -1 & -29 \\
\hline SADC & 16 & 278 & 28 & 85 & 52 & -1 & 107 & -3 & -21 \\
\hline \multicolumn{10}{|l|}{ Sub-Saharan Africa } \\
\hline Subtotal & -211 & 712 & -223 & -314 & -128 & -2 & -225 & -7 & -84 \\
\hline \multicolumn{10}{|l|}{ Middle East and } \\
\hline North Africa & -427 & 4046 & -626 & -441 & -9 & -342 & -162 & -13 & -283 \\
\hline South-East Europe & -111 & -41 & -17 & -18 & 0 & -6 & -8 & -2 & -8 \\
\hline Rest of World & -155 & -4 & -25 & -26 & 3 & 6 & 8 & 1 & -34 \\
\hline \multicolumn{10}{|l|}{ Developing } \\
\hline Countries & 2050 & 19855 & 8533 & 8591 & -171 & -454 & -570 & 803 & 8273 \\
\hline World & 41564 & 17551 & 8124 & 8137 & -203 & -681 & -871 & 516 & 8411 \\
\hline
\end{tabular}

Source: GTAP simulations. 


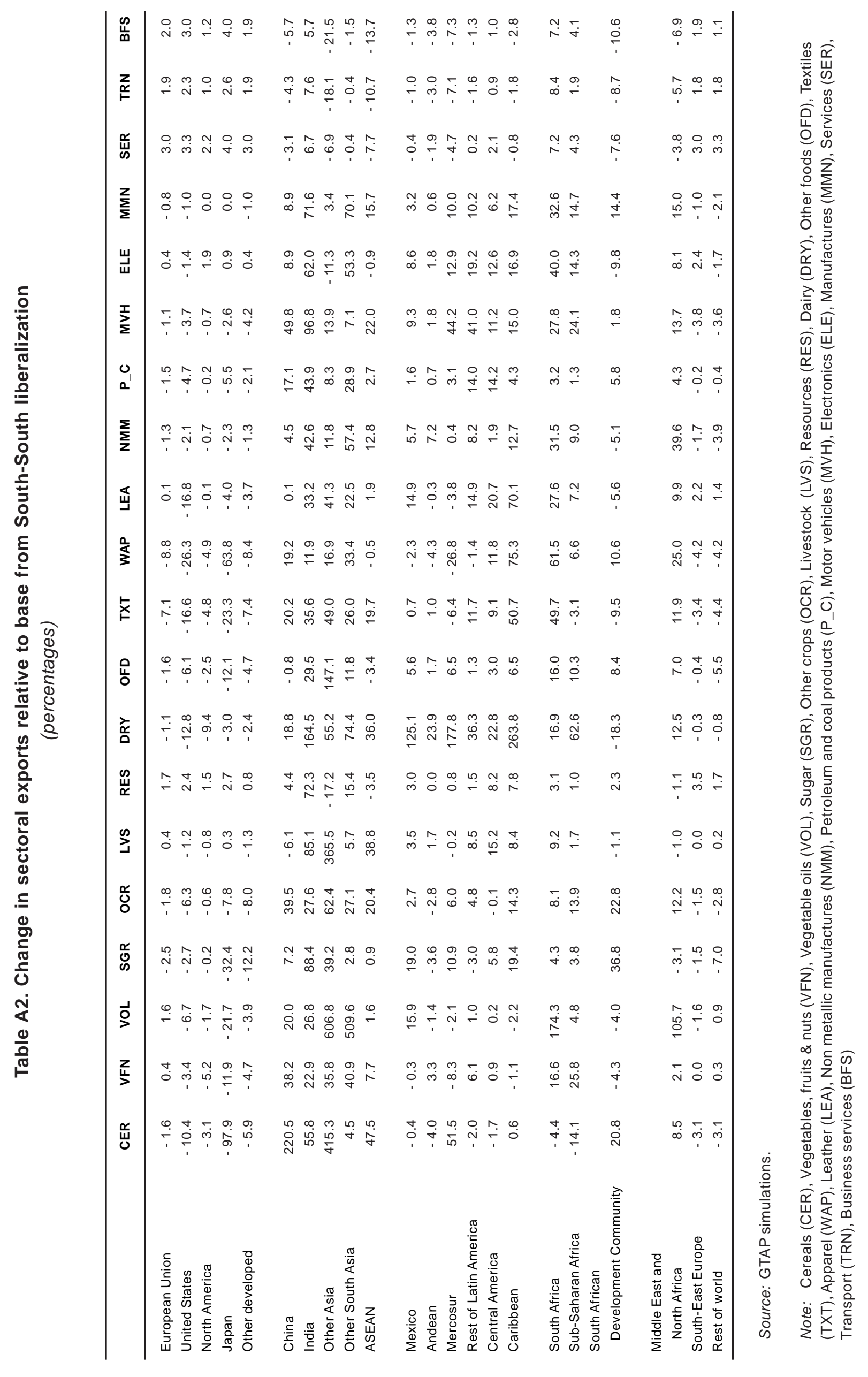




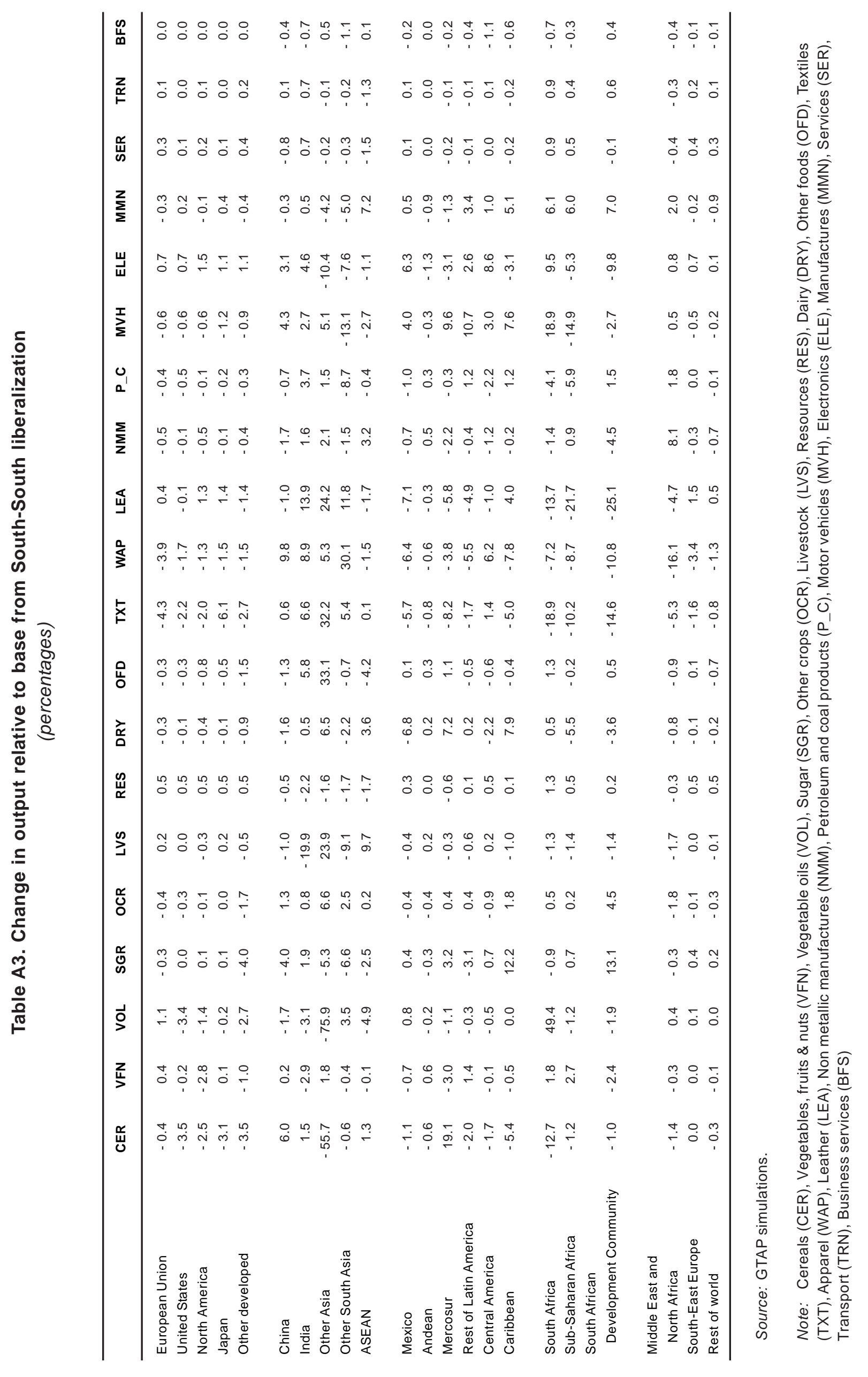




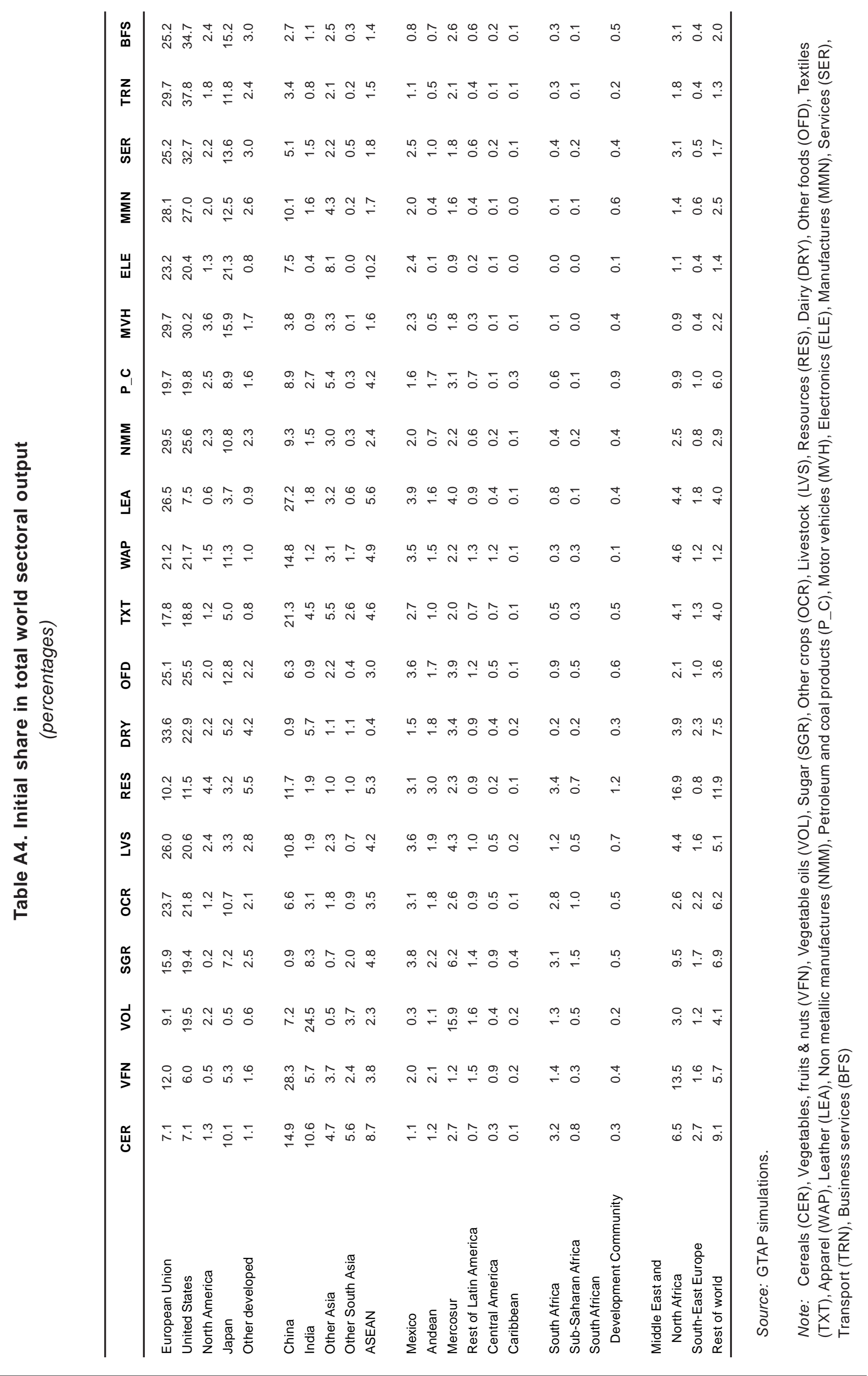




\section{POLICY ISSUES IN INTERNATIONAL TRADE AND COMMODITIES}

No. 1 Erich Supper, Is there effectively a level playing field for developing country exports?, 2001, 138 p. Sales No. E.00.II.D.22.

No. 2 Arvind Panagariya, E-commerce, WTO and developing countries, 2000, 24 p. Sales No. E.00.II.D.23.

No. 3 Joseph Francois, Assessing the results of general equilibrium studies of multilateral trade negotiations, 2000, 26 p. Sales No. E.00.II.D.24.

No. 4 John Whalley, What can the developing countries infer from the Uruguay Round models for future negotiations?, 2000, 29 p. Sales No. E.00.II.D.25.

No. 5 Susan Teltscher, Tariffs, taxes and electronic commerce: Revenue implications for developing countries, 2000, 57 p. Sales No. E.00.II.D.36.

No. 6 Bijit Bora, Peter J. Lloyd, Mari Pangestu, Industrial policy and the WTO, 2000, 47 p. Sales No. E.00.II.D.26.

No. 7 Emilio J. Medina-Smith, Is the export-led growth hypothesis valid for developing countries? A case study of Costa Rica, 2001, 49 p. Sales No. E.01.II.D.8.

No. 8 Christopher Findlay, Service sector reform and development strategies: Issues and research priorities, 2001, 24 p. Sales No. E.01.II.D.7.

No. 9 Inge Nora Neufeld, Anti-dumping and countervailing procedures - Use or abuse? Implications for developing countries, 2001, 33 p. Sales No. E.01.II.D.6.

No. 10 Robert Scollay, Regional trade agreements and developing countries: The case of the Pacific Islands' proposed free trade agreement, 2001, 45 p. Sales No. E.01.II.D.16.

No. 11 Robert Scollay and John Gilbert, An integrated approach to agricultural trade and development issues: Exploring the welfare and distribution issues, 2001, 43 p. Sales No. E.01.II.D.15.

No. 12 Marc Bacchetta and Bijit Bora, Post-Uruguay round market access barriers for industrial products, 2001, 50 p. Sales No. E.01.II.D.23.

No. 13 Bijit Bora and Inge Nora Neufeld, Tariffs and the East Asian financial crisis, 2001, 30 p. Sales No. E.01.II.D.27. 
No. 14 Bijit Bora, Lucian Cernat, Alessandro Turrini, Duty and quota-free access for LDCs: Further evidence from CGE modelling, 2002, 130 p. Sales No. E.01.II.D.22.

No. 15 Bijit Bora, John Gilbert, Robert Scollay, Assessing regional trading arrangements in the Asia-Pacific, 2001, 29 p. Sales No. E.01.II.D.21.

No. 16 Lucian Cernat, Assessing regional trade arrangements: Are South-South RTAs more trade diverting?, 2001, 24 p. Sales No. E.01.II.D.32.

No. 17 Bijit Bora, Trade related investment measures and the WTO: 1995-2001, 2002.

No. 18 Bijit Bora, Aki Kuwahara, Sam Laird, Quantification of non-tariff measures, 2002, 42 p. Sales No. E.02.II.D.8.

No. 19 Greg McGuire, Trade in services - Market access opportunities and the benefits of liberalization for developing economies, 2002, 45 p. Sales No. E.02.II.D.9.

No. 20 Alessandro Turrini, International trade and labour market performance: Major findings and open questions, 2002, 30 p. Sales No. E.02.II.D.10.

No. 21 Lucian Cernat, Assessing south-south regional integration: Same issues, many metrics, 2003, 32 p. Sales No. E.02.II.D.11.

No. 22 Kym Anderson, Agriculture, trade reform and poverty reduction: Implications for Sub-Saharan Africa, 2004, 30 p. Sales No. E.04.II.D.5.

No. 23 Ralf Peters and David Vanzetti, Shifting sands: Searching for a compromise in the WTO negotiations on agriculture, 2004, 46 p. Sales No. E.04.II.D.4.

No. 24 Ralf Peters and David Vanzetti, User manual and handbook on Agricultural Trade Policy Simulation Model (ATPSM), 2004, 45 p. Sales No. E.04.II.D.3.

No. 25 Khalil Rahman, Crawling out of snake pit: Special and differential treatment and post-Cancun imperatives, 2004.

No. 26 Marco Fugazza, Export performance and its determinants: Supply and demand constraints, 2004, 57 p. Sales No. E.04.II.D.20.

No. 27 Luis Abugattas, Swimming in the spaghetti bowl: Challenges for developing countries under the "New Regionalism", 2004, 30 p. Sales No. E.04.II.D.38.

No. 28 David Vanzetti, Greg McGuire and Prabowo, Trade policy at the crossroads The Indonesian story, 2005, 40 p. Sales No. E.04.II.D.40.

No. 29 Simonetta Zarrilli, International trade in GMOs and GM products: National and multilateral legal frameworks, 2005, 57 p. Sales No. E.04.II.D.41. 
No. 30 Sam Laird, David Vanzetti and Santiago Fernández de Córdoba, Smoke and mirrors: Making sense of the WTO industrial tariff negotiations, 2006, Sales No. E.05.II.D.16.

No. 31 David Vanzetti, Santiago Fernandez de Córdoba and Veronica Chau, Banana split: How EU policies divide global producers, 2005, 27 p. Sales No. E.05.II.D.17.

No. 32 Ralf Peters, Roadblock to reform: The persistence of agricultural export subsidies, 2006, 43 p. Sales No. E.05.II.D.18.

No. 33 Marco Fugazza and David Vanzetti, A South-South survival strategy: The potential for trade among developing countries, 2006, 25 p.

United Nations publications may be obtained from bookstores and distributors throughout the world. Please consult your bookstore or write to:

\section{United Nations Publications}

All orders from North America, Latin America, the Caribbean and Asia and the Pacific should be sent to:

United Nations Publications

Room DC2-853, 2 UN Plaza

New York, NY 10017, USA

Telephone: (212) 963-8302, Toll Free 1-800-253-9646 (North America only)

Fax: (212) 963-3489

E-mail: publications@un.org

Customers in Europe, Africa and the Middle East should send their orders to:

Section des Ventes et Commercialisation

Bureau E-4, CH-1211

Geneva 10, Switzerland

Telephone: 41 (22) 917-2613/2614

Fax: 41 (22) 917-0027

E-mail:unpubli@unog.ch 



\title{
QUESTIONNAIRE
}

\section{UNCTAD Study Series on \\ POLICY ISSUES IN INTERNATIONAL TRADE \\ AND COMMODITIES}

(Study series no. 33: A South-South survival strategy:

The potential for trade among developing countries)

\section{Readership Survey}

Since 1999, the Trade Analysis Branch of the Division on International Trade in Goods and Services, and Commodities of UNCTAD has been carrying out policy-oriented analytical work aimed at improving the understanding of current and emerging issues in international trade of concern to developing countries. In order to improve the quality of the work of the Branch, it would be useful to receive the views of readers on this and other similar publications. It would therefore be greatly appreciated if you could complete the following questionnaire and return to:

\author{
Trade Analysis Branch \\ DITC, Rm. E-8076 \\ United Nations Conference on Trade and Development \\ Palais des Nations \\ CH-1211 Geneva 10, Switzerland
}

1. Name and address of respondent (optional):

2. Which of the following describes your area of work?

$\begin{array}{llll}\text { Government } & \square & \text { Public enterprise } & \square \\ \text { Private enterprise institution } & \square & \text { Academic or research } & \square \\ \text { International organization } & \square & \text { Media } & \square \\ \text { Not-for-profit organization } & \square & \text { Other (specify) }\end{array}$

3. In which country do you work?

4. $\quad$ Did you find this publication $\quad \square$ Very useful $\quad \square$ Of some use $\quad \square$ Little use to your work?

5. What is your assessment of the contents of this publication?

$\square$ Excellent $\square$ Good $\square$ Adequate $\square$ Poor

6. Other comments: 
Ref.: UNCTAD/ITCD/TAB/34

July 2006

Geneva

\section{A SOUTH-SOUTH SURVIVAL STRATEGY: THE POTENTIAL FOR TRADE AMONG DEVELOPING COUNTRIES}

\section{Corrigendum}

$\underline{\text { Page } 3}$

The first paragraph should read:

Trade-weighted tariffs are averaged by imports, but it is instructive to look at the trade flows themselves to gauge the likely impacts. These are shown in table 3. Total trade in merchandise at world prices amounts to \$5.5 trillion (2001) (excluding intra-EU trade). Developed countries import \$1.8 trillion from other developed countries and slightly more than $\$ 1.2$ trillion from developing (including least developed) countries. Developing countries themselves import a greater proportion of their imports from developed countries (\$1.19 trillion versus $\$ 0.9$ trillion) but South-South trade is a substantial proportion nonetheless. Taking into account trade flows, the imputed tariff revenues collected by developed countries amounts to $\$ 76$ billion. By contrast, developing countries are collecting an estimated $\$ 152$ billion. Of this, $\$ 83$ billion is on imports from developed countries and $\$ 69$ billion on imports from other developing countries.

Page 3, table 3, subheading

Page 6, table 6, subheading

For (Thousands of US dollars) read (Millions of US dollars)

Page 8, table 7, subheading

Page 10 , table 8 , subheading

For (Thousands of US dollars and percentages) read (Millions of US dollars and percentages)

Page 12, table 9, subheading

Pages 16-17, table A1, subheading

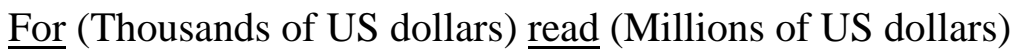

